\title{
COMPARISON OF THE EFFECTIVENESS OF REFRACTORY MATERIALS IN THE PREPARATION OF A TUNDISH FOR CONTINUOUS CASTING
}

\author{
${ }^{1}$ Martin LAMPA, ${ }^{2}$ Andrea SAMOLEJOVÁ \\ VSB - Technical University of Ostrava, Ostrava, Czech Republic, EU, \\ 1'martin.lampa@vsb.cz, ${ }^{2}$ andrea.samolejova@vsb.cz
}

https://doi.org/10.37904/metal.2021.4290

\begin{abstract}
Continuous steel casting has become a major technical and economic advantage one of the most important technological innovations not only in the steel industry, but in the world metallurgical industry in general. The aim of these modernization steps in the steel industry is focus on the production of high and super pure steels, which also has a significant impact on the use and thus also for the production and development of refractory materials.

It is the issue of refractory materials for the preparation of the working lining of the tundish for continuous casting that this article deals with, in terms of efficiency, use and complexity of preparation.

The aim of the article is generally to compare two methods of work preparation linings for tundishes for continuous casting of steel in terms of expected savings, increasing the quality of steel and accelerating the preparation of tundishes for the work process. Guniting and dry mix technologies are compared.
\end{abstract}

Keywords: Metallurgy, steel, continuous casting, guniting, dry mix

\section{INTRODUCTION}

Modern iron and steel metallurgy focuses primarily on an improving the quality, effectiveness and competitiveness of its production. In addition to the expected effects on quality and price, the introduction of new metallurgical processes today represents higher savings. In relation to this, and also due to the high demands on fuel, energy, raw materials and investment in metallurgical production, changes primarily provide increases in user properties and the final degree in metallurgy products, along with increases in the overall effectiveness of metallurgy production. Thanks to its significant technical-economic advantages, continuous steel casting is one of the most important technological innovations not only in the steel industry but in the global metallurgical industry generally. These steps of modernisation in the steel industry are directed towards the use and therefore the production and development of refractory materials.

\section{CURRENT DEVELOPMENTS IN REFRACTORY MATERIALS}

Current developments in refractory materials have led to their increased life span, management of ecological problems during production and use, and relate to attaining the maximum ceramic functionality. The main strategic aims are:

- Research and development of new, high-quality types of non-shaped refractory materials,

- Improvement of processes during repairs of linings while hot,

- Use of new raw materials (natural and synthetic) for the production of new composite materials,

- $\quad$ Study of product microstructure to improve their user properties, 
- Development of composite materials for more demanding conditions of use (very high temperatures, chemical corrosion, thermal shock, etc.),

- Development of new technologies for creating refractory concrete prefabricates,

- Improvement in the manufacturing process for the production of bricks with high aluminium content and alkaline bricks to improve their quality parameters [1].

\subsection{Refractory materials for raw iron and steel manufacturing}

In recent years, individual metallurgy plants have seen a distinct increase in life span due to the use of new refractory materials with high user value and the introduction of new installation techniques. The guaranteed life span of blast furnaces has risen to 20 years, the life span of converters now exceeds 30 thousand batches, and the life span of casting ladles has risen to 200-300 castings. Today, the slide gates of large casting ladles achieve around 10 castings, the lifespan of the refractory lining of a tundish has exceeded 70 sequences, and the life span of submerged nozzles has reached 12 hours of casting (Table 1). All of this has led to a reduction in the specific consumption of refractory materials during steel production and the attainment of better economic results during their production [2].

Table 1 Specific refractory material consumption during the production of raw iron and steel [1]

\begin{tabular}{|c|c|c|c|}
\hline Metallurgical plant & $\begin{array}{c}\text { Specific refractory material } \\
\text { consumption (kg/t) }\end{array}$ & $\begin{array}{c}\text { Proportion of total } \\
\text { consumption (\%) }\end{array}$ & $\begin{array}{c}\text { Proportion of non- } \\
\text { shaped material (\%) }\end{array}$ \\
\hline $\begin{array}{c}\text { Blast furnace: } \\
\text { Sealing material }\end{array}$ & $0.4-0.8$ & 3 & 100 \\
$-\quad$ Channel material+other & $0.4-1.2$ & 5 & $90-100$ \\
\hline Torpedo mixer, pouring ladle & $0.3-0.4$ & 3 & $25-35$ \\
\hline Oxygen converters & $0.8-2.0$ & 8 & $25-45$ \\
\hline Electric arc furnace & $4.7-6.3$ & 20 & $60-70$ \\
\hline Vacuum equipment & $1.0-1.5$ & 7 & $40-60$ \\
\hline Casting ladle: & & & $20-45$ \\
- oxygen converter steel mill & $0.8-3.0$ & 13 & $10-25$ \\
\hline - electric steel mill & $4.5-5.5$ & 20 & $65-85$ \\
\hline Tundish & $0.2-1.6$ & 18 & 0 \\
\hline Continuous casting & $02 .-0.3$ & 3 & \\
\hline
\end{tabular}

\subsection{Refractory materials and casting ceramics for continuous casting equipment (CCE)}

The technology for continuous steel casting places significant demands on the development and introduction of new high-quality materials for production because refractory ceramics are exposed to extremely demanding working conditions in CCE. The use of high-quality refractory materials for continuous casting is a basic prerequisite for fault-free operation of CCE. During continuous casting, many refractory ceramic components which come into contact with molten steel are used. In addition to the tundish and its lining, other components include the ladle shroud, mono block stopper, stopper mechanism, upper nozzles, submerged nozzles, argon purging bricks, baffles and impact pads. The operational reliability and life span of ceramic components and refractory linings during continuous steel casting is limited, and the limiting factor of their lifespan is the length of the sequence.

One important fact during continuous steel casting is that each CCE has its own specific conditions, and therefore the individual nodes may require a corresponding solution concerning the use of special ceramic materials [3]. 


\subsection{Function of refractory materials during continuous casting}

The basic functions of the refractory materials which come into contact with molten steel in the casting ladle and tundish (TD) include:

- Even and regulated feed of molten metal from the casting ladle to the tundish and from the tundish to the crystalliser,

- $\quad$ Protection from oxidation of the molten metal flowing from the casting ladle to the tundish and from the tundish to the crystalliser,

- During casting, maintaining the molten steel in the TD at approximately a constant temperature through the use of a suitable heat insulating lining with concurrent preservation of sufficient resistance to corrosion,

- Increasing the purity of the steel and optimising the flow of molten material in the TD [4].

\section{TECHNOLOGY FOR TUNDISH LINING PREPARATION}

The main function of the working lining in the tundish is to protect its permanent, non-working lining, i.e., elimination of solidified steel residues at the end of the sequence without damage to the permanent lining.

\subsection{Technology of guniting preparation}

This technology for the preparation of the tundish creates a working lining by spraying gunite, i.e., a dry mix based on $\mathrm{MgO}$ with added water. Use of this method spread throughout the world at the end of the 1980s, the main reason being better control of the gunite spray thickness than in preceding technologies.

Let us present the procedure for preparation of the working lining by guniting. First, the used protective layer is removed from the permanent lining (refractory concrete). The walls of the tundish should be around $60{ }^{\circ} \mathrm{C}$ before spraying, which is achieved through preheating from a lid with two burners for 60 minutes. The gunite is sprayed onto the prepared TD using a special device called a guniting machine. The dry mix is combined with approximately $23 \%$ water and then forced through a tube into a nozzle, from which it is sprayed onto the permanent lining of the tundish using compressed air. The aim is to spread the layer of gunite onto the walls and bottom of the TD as evenly as possible. The gunite is applied to the walls and bottom in three layers, the thickness of the resultant working lining being around $7 \mathrm{~cm}$, depending on the quality of the material and properties of the covering slag and steel. The process takes approximately 50 minutes and is performed by two people, one operating the guniting machine and the other performing the spraying in the TD using a spray pistol. After the gunite has been sprayed onto the TD, it must be left in the open to cure for an hour. This is followed by drying of the working lining using drying equipment, and once again placing the lid with two burners onto the sprayed TD for 4.5 hours at $350^{\circ} \mathrm{C}$. After drying, the TD is prepared for so-called "armouring", which means installation of other parts (refractory ceramics, hydraulics, lid of the TD) required for operation of the TD to cast steel. A TD armoured in this way can be used for high-temperature heating and subsequent inclusion in the working process, i.e., steel casting.

\subsection{Technology of dry mix preparation}

This technology does not use water, and instead of gunite, it uses a so-called dry mix. This is a mix of fired magnesium, sometimes including olivine and fibres containing a powder sealing additive. This method was first presented in 1986, and initially the materials were in the form of a dry powder, cured and then preheated before use. Later developments showed that cold starts (without high-temperature preheating) could be performed with this type of working lining.

The procedure for preparing the working lining with a dry mix begins in the same manner as for guniting, i.e., at the beginning the old protective layer is removed from the permanent lining (refractory concrete) of the TD. 
The walls of the TD need not be preheated. First, the dry mix is poured into the bottom of the TD using a simple hopper with a sleeve suspended from a gantry crane $26(\mathrm{~J}-5 \mathrm{t})$ to create a layer of around $7 \mathrm{~cm}$. The main principle is placing a steel mould in the middle of the TD so that there is approximately the same distance between the walls of the TD and mould all the way around-approximately $7 \mathrm{~cm}$. After the mould is successfully centred, the dry mix is poured into the gap up to the brim of the walls. This process lasts 20 minutes and is also performed by two people. One uses a controller to operate the gantry crane on which the hopper containing the material is suspended above the gap where the material is filled, and the other guides the poured material using the sleeve running from the hopper. In contrast to guniting, subsequent maturing is unnecessary, and material can be cured immediately using the applied lid with two burners on the filled tundish for 2.5 hours at $400^{\circ} \mathrm{C}$. The flames heat the inner walls of the mould, strengthening the dry mix. After this, the mould must be left in an open space for 60 minutes to cool down. Then it is carefully withdrawn from the TD and given a graphite coating so that during subsequent use and curing it is not baked onto the working layer of the TD. The tundish and its dry cured protective layer is once again ready for "armouring", which is identical to TDs prepared with gunite, and it may be used immediately for high-temperature heating and steel casting.

\subsection{Fundamental differences between the technologies}

The fundamental differences in preparation of the protective layer of the TD with gunite and dry mix are given in Table 2.

Table 2 Fundamental differences in preparation of the protective layer of the TD with gunite and dry mix

\begin{tabular}{|c|c|c|}
\hline TD preparation procedure & Guniting technology & Dry mix technology \\
\hline $\begin{array}{c}\text { Preheating the TD before } \\
\text { application of the working lining }\end{array}$ & $60 \mathrm{~min}$ & - \\
\hline Creation of the working lining & $50 \mathrm{~min}$ & - \\
\hline Maturing & $60 \mathrm{~min}$ & $150 \mathrm{~min}$ \\
\hline Drying & $270 \mathrm{~min}$ & $60 \mathrm{~min}$ \\
\hline Mould cooling & - & $120 \mathrm{~min}$ \\
\hline
\end{tabular}

The figures in the table show that dry mix preparation is less time consuming, which should also reflect lower costs in the use of this technology.

\section{TIME REQUIRED FOR THE PREPARATION OF THE TUNDISH}

This includes all the activities and operations directly associated with preparing the tundish from the beginning, i.e., tundish with remnants of sows after the end of pouring to the end, i.e., final form of tundish with a new working lining heated to $1100^{\circ} \mathrm{C}$. An assessment of the gross working time and the net working time associated with the overall preparation of the TD will be presented.

\subsection{Total TD preparation time with gunite}

The overall preparation time consists of several successive operations. All the activity associated with preparation of the working lining with gunite takes 1550 minutes if we assume that the average time for hightemperature heating totals 450 minutes. We must distinguish how much of this total time is down to the human factor and how much is a technological pause (drying, curing, heating). The net working time for preparation is only 260 minutes, i.e., $16.8 \%$ of the total time. 


\subsection{Total TD preparation time with dry mix}

For the purposes of comparison, let us note the timeframe to prepare the TD protective layer with dry mix under the same conditions as the start and end of preparation before use in the working process. The total preparation of the TD's working lining with dry mix takes 990 minutes, of which the crew's net working time is 210 minutes, i.e., $23 \%$ of the total time.

\subsection{Comparison of both technologies in terms of time}

Through a comparison, we discover (Figure 1 and Figure 2) that the overall preparation of the TD with dry mix is 560 minutes quicker than preparation of the TD with guniting, and the net working time of the crew expended for dry mix is 50 minutes shorter. These differences in time also affect the preparation phases, which are given in Table 2. So far, it has been ascertained that the dry mix technology is quicker, more effective and less demanding on time. The following chapter describes the costs expended on both technologies.

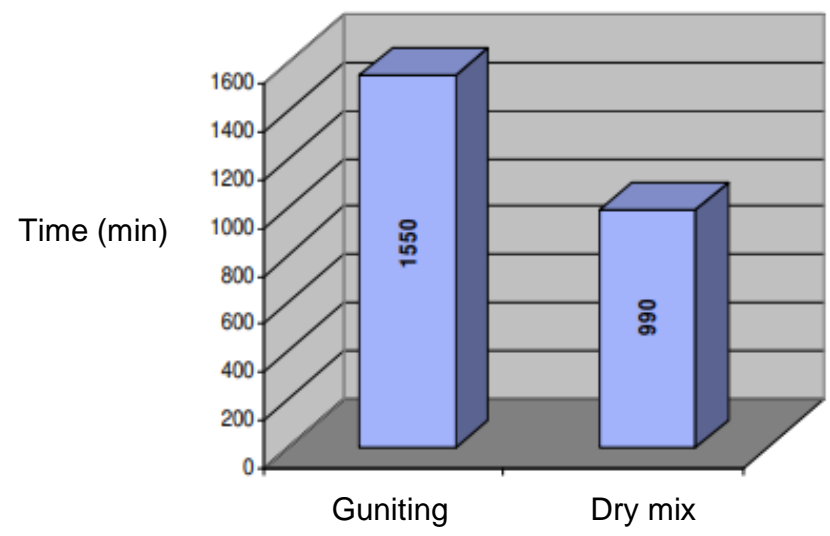

Figure 1 Total times for the preparation of TD using guniting or dry mix

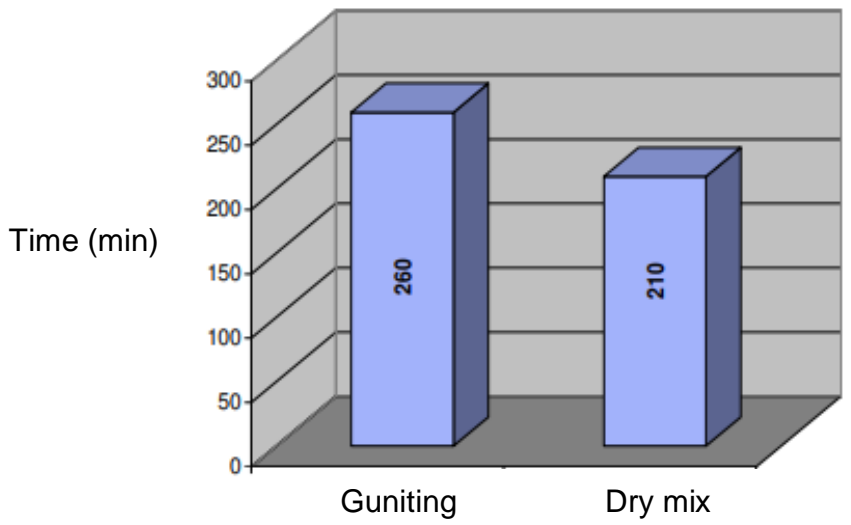

Figure 2 Net working times of the crew for the preparation of TD using guniting or dry mix

\section{COSTS FOR THE PREPARATION OF TUNDISH}

The fundamental matter for corporate costs is the fact that they are always in some way linked according to a purpose with corporate outputs. In practice, this means that any cost expended in the business should be linked according to purpose with the value expression of the benefit, i.e., the sold output. If this were not the case, they would not be costs but rather resources which, in a certain respect, we have wasted [5].

From the aspect of comparison between the two technologies, we consider material costs, costs for natural gas, electrical energy, water and repairs, but only from a general perspective. 


\subsection{Cost items for the preparation of TD by guniting}

Selected cost items:

- Guniting machine - equipment with a value running into hundreds of thousands of Czech crowns, but which is usually provided free of charge by the supplier of the mix or lent when a long-term contract is concluded with the regular purchase of refractory materials,

- $\quad$ Material (gunite) - consumption $1.8 \mathrm{t} / \mathrm{TD}$, where $1 \mathrm{t}=€ 370$,

- Natural gas - consumption $81 \mathrm{~m}^{3} / \mathrm{TD}$ (drying $10 \mathrm{~m}^{3}$, heating - average $71 \mathrm{~m}^{3}$ ),

- $\quad$ Electrical energy - consumption $47 \mathrm{kWh} / \mathrm{TD}$ (operation of machine, drying, heating),

- Water - consumption 720 I/TD,

- $\quad$ Spare parts for the guniting machine - approximately CZK 30,000/year,

- Refractory concrete - this is the non-working (permanent) lining of the TD, where we do not look at the costs per TD, which are the same for both technologies (approximately CZK 160,000 per TD), but life span, which is 1300 batches.

\subsection{Cost items for the preparation of TD with dry mix}

Selected cost items:

- Steel mould of TD + hopper (life span 10 years) - value in the tens of thousands of Czech crowns,

- Material (dry mix) - consumption $2.0 \mathrm{t} / \mathrm{TD}$, where $1 \mathrm{t}=€ 410$,

- $\quad$ Graphite - consumption $5 \mathrm{~kg} / \mathrm{TD}$, where $1 \mathrm{t}=\mathrm{CZK} 25,000$,

- $\quad$ Natural gas - consumption $36 \mathrm{~m}^{3} / \mathrm{TD}$ (curing $6 \mathrm{~m}^{3}$, heating $30 \mathrm{~m}^{3}$ ),

- Electrical energy - consumption $10 \mathrm{kWh} / \mathrm{TD}$ (operation of machine, hopper, heating,

- Refractory concrete (life span) $-1,800$ batches.

\subsection{Cost comparison of both technologies}

Table 3 Comparison of selected cost items for guniting and dry mix technologies

\begin{tabular}{|l|c|c|c|}
\hline \multicolumn{1}{|c|}{ Item } & Guniting technology (\%) & Dry mix technology (\%) & $\begin{array}{c}\text { Saving/loss for dry mix } \\
\text { technology (\%) }\end{array}$ \\
\hline Material & 90 & 100 & -10 \\
\hline Guniting machine & 100 & 0 & +100 \\
\hline Mould & 0 & 100 & -100 \\
\hline Electrical energy & 100 & 21 & +79 \\
\hline Natural gas & 100 & 44 & +56 \\
\hline Water & 100 & 0 & +100 \\
\hline Life span of TD & 100 & 72 & +28 \\
\hline Spare parts & 100 & 10 & +90 \\
\hline
\end{tabular}

We cannot state unambiguously that under the current conditions either of the evaluated technologies for the preparation of the TD's working lining is better from a cost perspective. Table 3 shows that the dry mix technology is cheaper because there is a saving on most items. But we should also be aware that material constitutes the greatest proportion of costs (approximately $80 \%$ ), which is better with the guniting technology. To find the cheaper technology, we would have to perform a detailed calculation of all the costs involved in 
both technologies; however, given the current level of costs (influenced by various changes in dry mix technology since its introduction), guniting is the cheaper technology with the current price of materials. Therefore, to conclude the cost comparison, we can argue that selection procedures which reduce the costs of purchased material are significant since it only requires a small shift in material costs for the cheaper technology to become the more expensive option (Table 3).

\section{OVERALL COMPARISON OF GUNITING AND DRY MIX TECHNOLOGY}

From the results of an examination of all factors (current working and production conditions, production plan, price of purchased material, etc.) which affect the overall technology of guniting and dry mix technology during the preparation of the tundish lining, a comparison of both technologies could be made.

\subsection{Evaluation of guniting technology}

Advantages:

- Lower consumption of material (gunite),

- Lower price for material (gunite),

- No acquisition costs for the guniting machine (they are lent by the supplier of the dry mixes),

- Longer life span of working lining during casting.

Disadvantages:

- Higher consumption of electrical energy,

- Higher consumption of natural gas,

- Higher consumption of water,

- Longer total time for the preparation of the TD,

- Longer inter-sequence downtime (longer high-temperature heating is required),

- Longer net working time of workers to prepare the TD,

- Greater stress on the human body, i.e., work with a preheated TD (effect of radiant heat) and the effect of vibrations from the spray pistol when gunite is sprayed onto the walls of the TD,

- $\quad$ Higher costs for spare parts,

- $\quad$ Greater permanent wear, non-working lining (shorter life span of the TD).

\subsection{Evaluation of dry filling technology}

Advantages:

- Lower consumption of electrical energy,

- Lower consumption of natural gas,

- No consumption of water,

- Shorter time for overall preparation of the TD,

- $\quad$ Shorter working time for people to prepare the TD,

- Less demanding work procedure to create the protective lining,

- $\quad$ Lower permanent wear, i.e., non-working lining (longer life span),

- Higher steel quality, i.e., lower oxygen content during casting in the first melt sequence,

- Shorter inter-sequence downtime (shorter high-temperature heating),

- $\quad$ Minimal costs for spare parts. 


\section{Disadvantages:}

- Higher consumption of material (dry mix),

- Higher price of material (dry mix),

- Acquisition costs for the steel mould,

- Increased dust levels during the creation of the protective layer, shorter life span of the working lining during casting.

\section{CONCLUSION}

When the dry mix technology was first introduced, completely different conditions existed for the production, price and consumption of material, the inter-sequence downtime, and the steel quality, and we must not overlook the fact that since it has been applied, the technology has been modified in a manner which can affect the economic evaluation of the entire preparation both positively and negatively. The production of slabs is now half of what it was during the pre-crisis years, mainly short sequences are cast, planned inter-sequence pauses are longer, and the range of refractory material is greater. All this must be considered in a comparison of the factors. Under current conditions, dry mix technology is more advantageous economically from a cost perspective than guniting technology. If we consider only the total costs for creating the working linings of TDs, material constitutes the greatest proportion of costs and is greater in price and consumption for dry mix than gunite. Consequently, it is very important to pay proper attention to the consumption and price of the material. Only a detailed analysis of both technologies can show whether the currently preferred dry mix preparation is still advantageous, as it was when it was first introduced, or whether it is a loss-making technology under conditions today.

The results showed that tundish operation should be performed by the supplier as a comprehensive service. The preparation of a tundish for casting represents a comprehensive set of activities which can relatively accurately define and specify the required output. Consequently, this activity can be offered as a service which includes the creation of the permanent and working linings of the TD. The input is a used TD after casting into CCE has been completed, and the output is a repaired and dried tundish with a new working lining. The main principle of the comprehensive service would be the full transfer of responsibilities to ensure the material and the work for the supplier. In this case, the economic aspect of comprehensive service is critical. For the client, it means forming a clear idea of costs. Once the contract is concluded, the client can precisely calculate the costs for the tundish since these are unambiguously based on the volume of steel cast. Another benefit is the savings on labour which provides this type of this activity. For the supplier, a significant benefit is the possibility to plan production for a longer period because of the certainty in purchasing. This can be taken advantage of in obtaining more favourable conditions with raw materials suppliers by negotiating greater volumes and longer periods of supply. Agreement on a fixed price for a prepared TD will stimulate motivation to search more rigorously for savings in materials and other costs.

\section{ACKNOWLEDGEMENTS}

The work was supported by the specific university research of Ministry of Education, Youth and Sports of the Czech Republic No. SP2021/43.

\section{REFERENCES}

[1] Průmysl žárovzdorného materiálu. [online]. 2020. [viewed: 2020-12-12]. Available from: http://www.refrasil.cz/vyvoj/prezentace/

[2] STAROŇ, J., TOMŠU゚, F. Žiarovzdorné materiály - výroba, vlastnosti a použitie. 1. vyd. Bratislava: Alfa, 1992. 
[3] SCHINDLEROVÁ, J. et al. Parametry ovlivňující životnost keramiky pro plynulé odlévání oceli. In: Teorie a praxe výroby a zpracování oceli. Ostrava: Tanger, 2005, pp. 186-191.

[4] FRÖHLICHOVÁ, M., TATIČ, M. Špeciálna keramika vo výrobe ocele. In: Iron and Steelmaking. Ostrava: Tanger, 2008, pp. 35-40.

[5] POPESKO, B., PAPADAKI, Š. Moderní metody řízení nákladů. 2. vyd. Praha: Grada Publishing, 2016. 